\title{
HOW ARE PRODUCTIVITY AND SUSTAINABILITY SUB-SECTOR AGRICULTURE TOMATO ? (A Case for Nagari SalayoTanang Bukik Sileh)
}

\author{
Zul Azhar ${ }^{1}$, Hasdi Aimon ${ }^{2}$, Elida $^{3}$ \\ 1'zulazhar@fe.unp.ac.id Ekonomi, Universitas Negeri Padang \\ 2 hasdi_aimon@fe.unp.ac.id Fakultas Ekonomi, Universitas Negeri Padang \\ 3 elida@fpp.unp.ac.id Fakultas Parawisata dan Perhotelan,universitas Negeri Padang \\ Correspondence Author: zulazhar.unp@gmail.com
}

\begin{abstract}
This research explains and analyzes the productivity and sustainability of the tomato agricultural sub-sector. Productivity problems occur when farmers are harvested and the price decline is economically unfavorable for farmers. In addition, it will have an impact on sustainability as a center for tomato production. The survey was conducted on 100 farmers in Kenagarian Selayo, Tanah Bukik Sileh. The data is processed using the production model and agricultural costs to observe the productivity and sustainability of the tomato sub-sector. The research findings show that input factors still reduce return to scale and economic productivity still needs to be improved. The cost side is not economically efficient with a low variable cost coefficient. Therefore, the tomato sub-sector of agriculture will be threatened by unsustainability, if there is negligence by policy makers. It is recommended to the village government to create a rural production center for tomatoes and derivatives from tomato products to maintain the sustainability of the tomato production center.
\end{abstract}

Keywords: Productivity, Sustainability, decreasing returns to scale, and cost efficiency.

\section{A. Introduction}

The agricultural sector tends to experience fundamental problems with the growth of the agricultural sector; low productivity, low response to technology adoption, land fragmentation and failure of home industries where the risk of production increases and perhaps due to explanations to farmers. How farmers are also involved in product diversification or producing with multilevel companies by adopting certain agro-ecological zones. (Damiao \& Morabito, 2016) and (A, 2006).

Certain regions of the world are compatible with tomato farming, and tomatoes have become one of the raw materials for the home industry. So tomato farming not only focuses on efficiency and productivity issues, but has led to the application of technology both in tomoat agriculture and in the development of derivative products from tomatoes themselves. (Llorachmassana et al., 2017) and (Clavreul, Butnar, Rubio, \& King, 2017).

The focus on Nagari Bukik Sileh in Lembang Jaya District in Solok Regency is an area whose economic activities are engaged in agriculture. The potential agricultural sector in this field is the tomato agriculture sub-sector. Therefore, the development of the tomato agriculture sub-sector is very important in improving the welfare of the motorbike farmers in particular and the NagariBukikSileh community in general. In line with that, in line with the development policy of the agricultural sector is one of the priorities of national development policy. (Meck, Kennedy, \& Walgenbach, 2013) and (Yelapure \& Prof, 2011).

Hanani ARet.al (2003: 31) and Solok Regency Central Bureau of Statistics (BPS) in 2014, the contribution of the agricultural sector to the Gross Regional Domestic Product (GRDP) of Solok Regency was $39.66 \%$. The food and vegetable sub-sector is the largest contributor to 
agriculture, which is $15.03 \%$ of all agricultural value added. This is also in line with the research findings (Ayomide, Ajayi, Banjo, \& Ajayi, 2017) and (Liang, Jie, Kai, \& Wencai, 2017).

One type of vegetable plant that contributes enough to the economic development of the community in this area is vegetables with tomato plants. In 2012-2014 there were most harvest conditions for tomato production in Solok Regency. The occurrence of harvest conditions is indicated by the contribution of tomato production to the total production of the vegetable subsector reaching an average of 63.2\% (BPS, 2014). High yields can become oversupply in the regional market. Excess supply means high production rather than consumption. Data from Solok Regency BPS (2014) noted that around $42 \%$ of tomato production exceeds the consumption of tomatoes themselves. The consequence is that the price of tomatoes is cheap, many tomatoes are not sold so many tomatoes become rotten. In addition, many tomato farmers themselves suffer losses, so many professions change. In line with saying: (Zhu, Klee, \& Sarnoski, 2017) and (A, 2006).

Lembang Jaya Subdistrict in Solok Regency often experiences the highest harvest conditions compared to other sub-districts. Harvesting has implications for the high supply of tomatoes in this area. Based on data from BPS Lembang Jaya Inka (2014) where the excess supply of tomatoes compared to demand reached $58.3 \%$. This means that every two tomatoes only produce one tomato sold. The high supply of tomatoes in this area has made tomato farmers in Lembang Jaya District suffer the greatest losses due to harvests that occurred from 2012 2014 compared to tomato farmers in other districts.

In addition, the initial interview (June 2017) conducted at the Women Farmers' Group (KWT) in Kenagarian Selayo Tang Bukit Sileh stated that more than $45.7 \%$ of tomato production was not sold. This situation is caused by low demand (consumption) and too large production. For several the last year the situation has bound tomato farmers in this area and Solok District in general.

\section{B. Literature Review}

Manyong et al. (2005) stated that the most fundamental constraints to the growth of the agricultural sector were the production system, the low response to technology adoption, land fragmentation and the failure of home industries that increased the risk of production and explained to farmers how farmers were involved in product diversification or producing with multilevel companies by adopting special agro-ecological zones (Ajibefun, 2006). Diversification of home industries as an agricultural strategy is believed to gain a number of advantages: the ability to reduce risk, increase employment and employment opportunities, the ability to reduce diseases and attacks of pests and increase soil fertility in some cases (Damiao, C., \& Morabito, R. 2016 ) and (Bamji, MS, 2000) note that diversification in food crops and I or between plants and livestock increases nutritional security, especially for poor and marginal farmers.

Production is the end result of a process or economic activity by utilizing several inputs or inputs (Joesron, 2003: 77). With this understanding it can be understood that production activities are a combination of various inputs or inputs to produce output. The technical relationship between input and output in the form of equations, tables or graphs is a function of production. Meanwhile, according to Salvatore (2007: 75) argues that the production function is a physical relationship between the variables described (Y) and variables that explain (X). The variables described are usually outputs and variables which usually explain in the form of input. With the production function, researchers can know the relationship between production (input) 
and production (output) factors directly and the relationship can be better understood. In addition to the production function, researchers can find out the relationship between explanatory variable. Mathematically, this relationship can be explained as follows (Salvatore, 2007: 76):

$$
\mathrm{Y}=\mathrm{f}(\mathrm{X} 1, \mathrm{X} 2, \ldots \ldots, \mathrm{Xn})
$$

The production function has properties such as utility functions. If input increases, output also increases. But the first additional input will provide an additional output that is greater than the additional output caused by additional input later. This property is called the law of diminishing returns (Case \& Fair, 2007: 144).

Mankiw (2006: 336) says that every production process has a technical foundation, which in economic theory is called a production function. The production function is a function or equation that shows the relationship between the level of output and the level of combination of the use of inputs. Graphically, ceteris paribus, the work production function (L) (assumed $\mathrm{K}$ is fixed), then Q (L).

Mathematically, the nature of the production function rises (if the input increases, the output increases) indicated by the first derivative $\mathrm{Q}$ of $\mathrm{L}$ is positive. While the decreasing nature of the increase (describing the law of diminishing returns) is indicated by the second derivative $\mathrm{Q}$ of negative L (concave curve). Cobb-Douglas production function is an equation function that involves two or more variables. One variable is called dependent, which is explained (Y) and other variables are called independent variables that explain (X) (Bilas, 2008: 154). Completion of the relationship between $\mathrm{X}$ and $\mathrm{Y}$ is usually by way of regression, namely variation of $\mathrm{Y}$ will be influenced by variations of $\mathrm{X}$. The Cobb-Douglas production function is as follows (Rinse, 2008: 154):

$$
\mathrm{Q}=\mathrm{AK}^{\alpha} \mathrm{L}
$$

$\mathrm{Q}$ is the output quantity and L and $\mathrm{K}$ respectively are labor and capital goods $\alpha$ (alpha) and (betha) are positive parameters determined by data.

The characteristics of the Cobb-Douglas production function are as follows:

1) $\mathrm{K}$ and $\mathrm{L}$ can substitute each other

2) If labor becomes expensive, the company will substitute labor with capital. In this case, labor intensive technology is replaced by capital intensive technology. The substitution nature of these inputs follows the rules of Marginal Rate of Technical Substitution / Trasformation described by isoquant curve.

3) $\frac{\partial Q}{\partial K}, \frac{\partial Q}{\partial L}>0$, the marginal productivity of the production factors is positive. This formula shows the marginal product of capital and labor is positive. Marginal Product of Capital (MPP) and Marginal Product of Labor (MPL) depend on the level of output and the level of use of capital and labor.

4) $M P K=\alpha \frac{Q}{K} \operatorname{dan} M P L=\beta \frac{Q}{L}$

5) $\frac{\partial^{2} Q}{\partial K \partial K}, \frac{\partial^{2} Q}{\partial L \partial L}$

$<0$, the marginal productivity of its production factors follows the Law of Diminishing Returns. This property reflects that the Cobb-Douglas production function has a concave character, the implication is that the function has a maximum value. 
6) $\mathrm{Q}=(\mathrm{K}) \alpha(\mathrm{L})$, is: Constant Returns to Scale, if $(\alpha+\beta)=1$. That is, if the inputs $\mathrm{K}$ and $\mathrm{L}$ increase each to two times, then the output also increases twice. In this case, the output increases proportionally with the addition of inputs.

7) Increasing Returns to Scale, if $(\alpha+\beta)>1$. This means that if the inputs $K$ and $L$ are added to each of them twice, then the output also increases more than twice. In this case, output increases more than proportion with the increase in input.

8) Decreasing Returns to Scale, if $(\alpha+\beta)<1$. This means that if the inputs $\mathrm{K}$ and $\mathrm{L}$ increase respectively become two times, then the output increases less than twice. Output increases by less than the proportion of added inputs. This condition can occur because the complexity of the production process becomes very high if the scale of the operation becomes large. Decreasing Returns to Scale implies diseconomics to scale, ie the average cost will rise in line with the increase in the number of outputs.

\section{Research Methods}

The method in this study was conducted with a survey in the form of distributing questionnaires and research questionnaires. While the research was conducted on tomato farmer households in the area of Nagari Salayo Tanang Bukik Sileh, Solok Regency. because the population cannot be known with certainty through the Salayo Lake, Sileh Bukik, 100, the samples in the study were taken based on random samples area (Area Random Sampling) as follows;

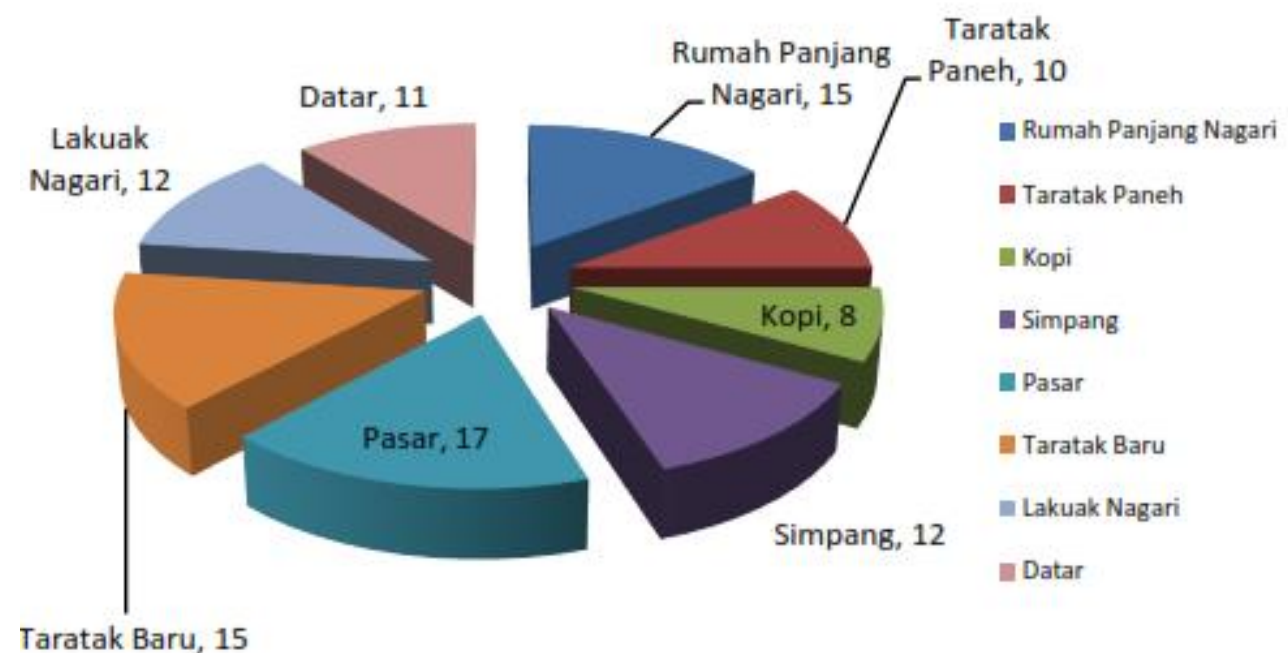

The analysis technique is derivative of the Cobb-Douglas production function model where: K (capital) and L (labor) can substitute for each other. The Total Production Model (TP) is Land Area (LL), plus Raw Material (BB) and Fertilizer (PP);

$\log (\mathrm{TP})=1 \log (\mathrm{LL})+2 \log (\mathrm{BB})+3 \log (\mathrm{PP})$

$\log ($ TPILL $)=\alpha 1 \log ($ BBILL $)+\alpha 2 \log ($ PPILL $)$ and $\mathrm{TC}=\mathrm{FC}+\mathrm{VC}$

\section{Research Results}

Total production (TP) of tomatoes is determined by the variation of input factors in this study determined by; a) land area (LL), b) Seedling costs (BB), and c) Fertilizer Costs (PP). The estimation results show that all input factors have a significant effect on total tomato production 
at alpha 1 percent. The contribution of these input factors to total tomato production is 62.48 percent. This means that there are other factors that determine the total tomato production which is not observed in this study according to (Azhar, 2017) such as; environmental studies, cultural socia, climate, irrigation systems, and other factors of 37, 52 percent. The estimation results can also be seen in the form of the LOG (TP) equation $=0.1667 \mathrm{LOG}(\mathrm{LL})+0,4512 \mathrm{LOG}(\mathrm{BB})+$ $0,3191 \mathrm{LOG}(\mathrm{PP})$.

Total tomato production in the Tanang Bukik Sileh area of Nagari Salayo is influenced by the area planted by farmers and is also influenced by the size of the cost of tomato seedlings and the cost of providing fertilizer. The results showed that total tomato production was affected positively by land area of 0.1667 percent and seedling costs of 0.4512 percent and was influenced by the cost of providing fertilizer by 0.3191 percent. This means that if the land area is increased by 1 percent, then tomato production will increase by 0.1667 percent and if the cost of the seed is increased by 1 percent, then tomato production will increase by 0.4512 , and if the cost of providing fertilizer is added by 1 percent, then the production tomatoes will increased by 0.3191. So, the decisive input factor is seedlings and fertilizer and new land area.

In addition, tomato production in Tanang Bukik Sileh's Nagari Salayo area shows that the input factors together contribute to 0.6248 or $62.48 \%$ of the total tomato production. The average tomato production in one planting period is 10.17 tons with a standard deviation amount of 0.43 . This means that the trend of Nagari Salayo Tanang Bukik Sileh's tomato production is between $9.74-10.17$ tons. So if small tomato production is from 9.74 tons in one planting period, it can be said that the farmer has a low level of ability to produce tomatoes as a tomato farmer. Then the factor production elasticity is still smaller than 1 , which is equal to 0.937 . This means that it is still a decreasing return to scale (DRTS). Therefore, tomato farmers in Tanang Bukik Sileh Nagari Salayo still need to increase their production capacity by fostering and counseling in building input factors so that they can change to increasing returns to scale (IRTS).

Log Model $(\mathrm{TC})=8.9672+0.6374 \log (\mathrm{TP})$ of Total Cost (Total Cost) of tomatoes is largely determined by the total amount of tomato production. The results of this study indicate that the total cost of tomato production is influenced by the total tomato production of 0.6374 . Thus it can be said that the total cost of producing tomatoes has an effect of 0.4860 or $48.60 \%$. The total cost of producing tomatoes is 15.45 tons with a standard deviation of 0.396 . This means that the trend of the total cost of producing tomatoes in Tanang Bukik Sileh Nagari Salayo is between 15.05-15.45 tons. So if the total production of tomatoes is small from 15.05 million, it can be said that the total cost of tomatoes due to total production is less effective in producing. Then the factor production elasticity is still smaller than 1 which is equal to 0.7769 . This means that it is still a decreasing return to scale (DRTS). Therefore, tomato farmers in Tanang Bukik Sileh Nagari Salayo still need to increase their production capacity by fostering and counseling in building input factors so that they can change to increasing returns to scale (IRTS).

\section{E. Conclusion}

The total production (TP) of Sileh Hill tomatoes is largely determined by the area of land, the amount of tomato seedlings added to the amount of fertilizer given to tomato plants. Total tomato production at harvest time is affected by seed costs and fertilizer costs. Then it can be said that total production due to seed costs and fertilizer costs are less efficient in producing. Then the production factor elasticity is still small than $<1$ which is a decreasing return to scale (DRTS). 
Furthermore, Total Cost (TB) of tomatoes is largely determined by the total amount of tomato production. The results of this study indicate that the total cost of tomato production is influenced by total tomato production. When viewed from the total production of tomatoes per hectare tomato land is largely determined by the amount of total production costs per hectare of tomato land. The results of this study indicate that the total production of tomatoes per hectare of tomato land is affected by the total production cost per hectare of tomato land. However, it needs to be examined further that the economic value of extensive land use is not necessarily efficient.

\section{F. References}

Ajibefun, I. (2006). Cropping System. Technical efficiency and policy options: A Stochastic Frontier Analysis of Niger small-scale farmers. Q. J. Int. Agric. $45,145-169$.

Altieri A., M. (1992). Sustainable Agricultural Development in Latin America: exploring the possibilies. Elsivier Science Publisher.

Azhar, Zul, U. N. P. (2013). Development Planning (Concepts, Theories, Models, Techniques, Applications).

Azhar, Z. (2017). Head of Environment and Development Planning; Textbooks). Padang: Faculty of Economics, Padang State University.

Bamji, M. S. (2000). Diversification of agriculture for human nutrition. Curr. Sci. Guvele, C.A. Gains from the Sudanese Gezira scheme diversification in the crop. Agric. Syst. 2001, 70, 319-333.

Manyong, V.M .; Ikpi, A .; Olayemi, J.K .; Yusuf, S.A .; Omonona, B. T. O., \& V .; Idachaba, F. S. (2005). Agriculturein Nigeria: Identifying Opportunities for Increased Commercialization and Investment. . IITA PublicationSeries: Ibadan, Nigeria, 159.

Rahman, Sanzidur and Chima D., C. (2016). Determinants of Food Crop Diversity and Profitability in Southeastern Nigeria: A Multivariate Tobit Approach. Agriculture Journal, MDPI.

Singh, S. (2000). Contract farming for agricultural diversification in the Indian Punjab: A study of performance and problems. Indian J. Agric. Econ. 2.

Van den Berg, M.M .; Hengsdijk, H .; Wolf, J .; Ittersum, M.K.V .; Guanghuo, W.., \& Roetter, R.. (2007). The impact of increasing farm size and mechanization on rural income and rice production in Zhejiang province. China. Agric. Syst.

Yaron, G. (1998). Alternative Land Use Options in the Mount Cameroon Region: An Economic Analysis. The Center for Social and Economic Research on the Global Environment. 